\title{
Effect of selenium on cadmium uptake in selected benthic invertebrates
}

\author{
Poul Bjerregaard \\ Institute of Biology, Odense University, Campusvej 55, DK-5230 Odense M, Denmark
}

\begin{abstract}
Effect of selenium on uptake of cadmium in the benthic marine invertebrates Asterias rubens, Mytilus edulis, Littorina littorea, and Arenicola marina was investigated in a series of laboratory experiments. A. rubens exposed to $200 \mu \mathrm{g} \mathrm{Cd} \mathrm{l^{-1 }}$ alone took up cadmium in body wall, pyloric caeca, and tube feet at initial rates of 1 to $2 \mu \mathrm{g} \mathrm{Cd} \mathrm{g}^{-1}$ dry wt d $\mathrm{d}^{-1}$; steady state concentrations of 10 to $30 \mu \mathrm{g}$ $\mathrm{Cd} \mathrm{g}^{-1}$ were reached after 1 to $2 \mathrm{wk}$. Concurrent exposure to $141 \mu \mathrm{g} \mathrm{Se-SeO}{ }_{3}^{--} \mathrm{l}^{-1}$ increased cadmium uptake rates to 5 to $10 \mu \mathrm{g} \mathrm{Cd} \mathrm{g} \mathrm{d}^{-1}$; uptake proceeded linearly with time over $4 \mathrm{wk}$. Exposure to $200 \mu \mathrm{g}$

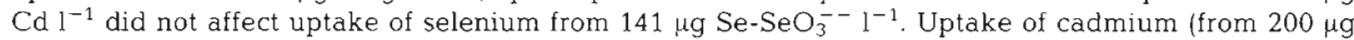
$\mathrm{Cd} \mathrm{l}^{-1}$ ) in tube feet and body wall was augmented by $17 \mu \mathrm{g} \mathrm{Se}-\mathrm{SeO}_{3}^{--} \mathrm{I}^{-1}$, whereas higher selenite concentrations were required to augment cadmium uptake in pyloric caeca. In specimens exposed to radioactive cadmium for $2 \mathrm{wk}$, selenite concentrations at and above $75 \mu \mathrm{g} \mathrm{Se-SeO}{ }^{--} \mathrm{l}^{-1}$ augmented cadmium uptake. A. rubens exhibited concentration factors (expressed on dry weight basis) for cadmium of ca 800 for ambient cadmium concentrations up to $3 \mu \mathrm{g} \mathrm{Cd} \mathrm{l^{-1 }}$; between 3 and $400 \mu \mathrm{g} \mathrm{Cd} 1^{-1}$, concentration factors decreased from 800 to 100 . When exposed to $200 \mu \mathrm{g} \mathrm{Cd}^{-1}$ alone, $M$. edulis took up cadmium at initial rates of $9.3,36,7.7,6.4,24$, and $0.8 \mu \mathrm{g} \mathrm{Cd} \mathrm{g} \mathrm{Cd}^{-1}$ dry wt d $\mathrm{d}^{-1}$ in mantle, digestive gland, foot, adductor muscle, gills, and shell, respectively, $L$. littorea took up cadmium at 11 and $0.6 \mu \mathrm{g}$ $\mathrm{Cd} \mathrm{g}^{-1}$ dry wt d ${ }^{-1}$ in soft parts and shell, and $A$. marina took up cadmium at 6.1 and $10.4 \mathrm{\mu g} \mathrm{Cd} \mathrm{g} \mathrm{gdr}^{-1}$ wt $\mathrm{d}^{-1}$ in body wall and gut and $0.23 \mu \mathrm{g} \mathrm{Cd} \mathrm{ml} l^{-1} \mathrm{~d}^{-1}$ in blood. Uptake proceeded linearly with time over $4 \mathrm{wk}$ exposure in mantle, digestive gland, foot, and adductor muscle of $M$. edulis, soft parts of $L$. littorina, and gut, body wall, and blood of A. marina. In the other tissues uptake rates declined after 1 to 2 wk of exposure. Exposure to an equimolar concentration $\left(141 \mu \mathrm{g} \mathrm{Se}-\mathrm{SeO}_{3}^{--} 1^{-1}\right)$ of selenite did not affect cadmium uptake in these 3 species. Exposure to a 5 -fold concentration of selenite $(703 \mu \mathrm{g} \mathrm{Se}$ $\mathrm{SeO}_{3}^{--} 1^{-1}$ ) augmented cadmium uptake in gills, mantle, and foot of $M$. edulis.
\end{abstract}

\section{INTRODUCTION}

Since the discovery that selenium protects rat testes against the toxic effects of cadmium (Kar et al. 1960), interactions between selenium and cadmium and mercury in mammals have been studied intensively (reviewed by Magos \& Webb 1980). Although the interaction between selenium and mercury in aquatic organisms has been investigated in some detail (reviewed by Pelletier 1985), the effect of selenium on cadmium uptake and toxicity in aquatic organisms is poorly understood.

Positive correlations between cadmium and selenium concentrations in black marlin Makaira indica (Mackay et al. 1975) and several species of marine birds (Norheim 1987) have been found. Selenium augments uptake of cadmium in gills and haemolymph of the shore crab Carcinus maenas (Bjerregaard 1982, 1985, 1988) and counteracts the toxic effects of cadmium in the freshwater snail Lymnaea stagnalis (Puymbroeck et al. 1982).

Selenium is present in unpolluted seawater in $\mathrm{ng} \mathrm{l}^{-1}$ quantities (Measures \& Burton 1980, Measures et al. 1980, Cutter \& Bruland 1984, Apte et al. 1986). Selenium concentrations in fresh and coastal waters may be augmented from anthropogenic sources such as drainage from irrigated and selenite-fertilized soils (Phillips 1987), leaching from fly-ash deposits (Ahsahnullah \& Brand 1985), and discharges from refineries (Phillips 1987). Fly-ash leachates and effluents from refineries may contain up to $2400 \mu \mathrm{g}$ Se $1^{-1}$ (Ahsanullah \& Brand 1985) and $150 \mu \mathrm{g} \mathrm{Se} \mathrm{l}^{-1}$ (Phillips 1987), which may locally augment the selenium concentration of the seawater to $\mu \mathrm{g} \mathrm{Se}^{-1}$. It is not known if discharges of selenium compounds in coastal and estuarine environments affect uptake of metals by organisms living in these habitats.

This study examines the effect of selenite on cad- 
mium uptake in sea stars Asterias rubens, mussels Mytilus edulis, periwinkles Littorina littorea, and lugworms Arenicola marina.

\section{MATERIALS AND ME'THODS}

Experimental animals. Sea stars Asterias rubens and periwinkles Littorina littorea were obtained from Lillebælt, Denmark. For Expt 2, sea stars were caught in seines, while those used in the remaining experiments were collected from the shore. Sea stars used in December were collected in October and kept in flowing seawater tanks at the Marine Biological Station, Bøgebjerggård, until they were brought to the laboratory. Lugworms Arenicola marina and mussels Mytilus edulis were collected in Denmark at Bregnør, NE Funen, and Kertinge Nor, E Funen, respectively.

Exposure procedures. Animals were acclimated in the laboratory for 1 to $5 \mathrm{~d}$ prior to experiment and then exposed to cadmium as $\mathrm{CdCl}_{2}$ and selenium as $\mathrm{Na}_{2} \mathrm{SeO}_{3}$. Details of exposure conditions in each experiment are given in Tables 1 and 2. Cadmium and (in some of the experiments) selinite concentrations in the aquaria were monitored, and unless otherwise stated concentrations varied by less than $10 \%$ between water changes. The water in the exposure aquaria was aerated and no sediment was placed in the aquaria. The animals were not fed during the experiments. Store Bælt seawater with background cadmium and selenite concentrations of ca $25 \mathrm{ng} \mathrm{Cd} \mathrm{l}^{-1}$ (Magnusson \& Rasmussen 1982) and less than $10 \mathrm{ng} \mathrm{Se}-\mathrm{SeO}_{3}^{--} \mathrm{l}^{-1}$ (Bjerregaard 1982) was used in the experiments.

Selenium analysis. Selenium concentrations in the tissues were determined by gas chromatography with a modified version of the technique described by Shimoishi (1976). The 5-nitropiaselenol produced (Shimoishi 1976) was extracted into toluene and $2 \mu$ samples were manually injected into a Hewlett Packard 5830 A Gas Chromatograph equipped with an

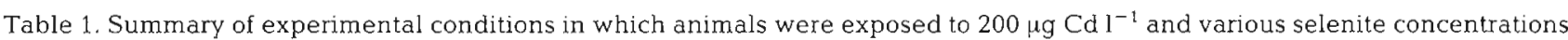

\begin{tabular}{|c|c|c|c|c|c|c|}
\hline $\begin{array}{l}\text { Organism } \\
\text { Experiment no. }\end{array}$ & $\begin{array}{l}\mu \mathrm{g} \mathrm{Se}-\mathrm{SeO}_{3}^{--} \\
\quad \text { added } 1^{-1}\end{array}$ & $\begin{array}{l}\text { Initial } \\
\text { no. of } \\
\text { animals }\end{array}$ & $\begin{array}{l}\text { Days of sampling } \\
\text { and no. of animals } \\
(n) \text { sampled }\end{array}$ & $\begin{array}{l}\text { Type and } \\
\text { volume } \\
\text { of aquaria }\end{array}$ & $\begin{array}{c}\text { Salinity (S \%o) } \\
\text { Temperature } \\
\left.\qquad{ }^{\circ} \mathrm{C}\right)\end{array}$ & $\begin{array}{c}\text { Size of animals } \\
\text { (g wet wt) } \\
\text { Date }\end{array}$ \\
\hline Asterias rubens & 0 & 25 & $5,10,14$ & $60 \mathrm{I}$ glass & $22-23$ & $20-50$ \\
\hline Expt 1 & 141 & 25 & $18,28(5)$ & aquaria & 15.5 & 13 Jun 1986 \\
\hline Asterias rubens & 0 & 5 & $21(4)$ & & & \\
\hline \multirow[t]{12}{*}{ Expt 2} & 2.2 & 5 & $21(3)$ & & & \\
\hline & 4.4 & 5 & $21(2)$ & & & \\
\hline & 8.8 & 5 & 21 (4) & 81 poly- & $21-23$ & $20-50$ \\
\hline & 17.6 & 5 & $21(4)$ & styrene & 15.5 & 30 Jul 1986 \\
\hline & 35 & 5 & $21(0)$ & aquaria & & \\
\hline & 70 & 5 & $21(2)$ & & & \\
\hline & 141 & 5 & $21(5)$ & & & \\
\hline & 281 & 5 & $21(5)$ & & & \\
\hline & 562 & 5 & $21(0)$ & & & \\
\hline & 1124 & 5 & $21(0)$ & & & \\
\hline & 2248 & 5 & $21(0)$ & & & \\
\hline & 4496 & 5 & $21(0)$ & & & \\
\hline Asterias rubens & $141^{\mathrm{a}}$ & 16 & $7(5), 17(5)$ & $30 \mathrm{l}$ glass & $23-24$ & $20-50$ \\
\hline Expt 3 & 141 & 16 & $28(6)$ & aquaria & 15.5 & 16 Dec 1986 \\
\hline Mytilus edulis & 0 & 21 & $7(5), 14(8)$ & 81 poly- & $22-24$ & $4.7-5.7^{c}$ \\
\hline \multirow[t]{2}{*}{ Expt 7} & 141 & 21 & $28(8)$ & styrene & 15.5 & 2 Jun 1985 \\
\hline & 703 & 21 & & aquaria & & \\
\hline Littorina littorea & 0 & 40 & $7,14,21$ & 81 poly- & $21-23$ & $41-128^{d}$ \\
\hline Expt 8 & 141 & 40 & $27(10)$ & $\begin{array}{l}\text { styrene } \\
\text { aquariab }^{b}\end{array}$ & 15.5 & 30 Jul 1986 \\
\hline Arenicola marina & 0 & 20 & $5,12,19$ & 81 poly- & $19-23$ & $10-18$ \\
\hline Expt 9 & 141 & 20 & $26(5)$ & $\begin{array}{l}\text { styrene } \\
\text { aquaria }\end{array}$ & 10.0 & 10 Oct 1985 \\
\hline \multicolumn{4}{|c|}{$\begin{array}{l}\text { No cadmium added } \\
\text { Equipped with a mesh to prevent the periwinkles from leaving the water phase } \\
\text { S Shell length (cm) }\end{array}$} & hase & & \\
\hline
\end{tabular}


Table 2. Asterias rubens. Summary of experimental conditions in Expts 4, 5, and 6. Each of the experimental groups initially consisted of 7 small sea stars ( 1 to $9 \mathrm{~g}$ wet wt) placed in 81 polystyrene aquaria containing ca $600000 \mathrm{dpm}{ }^{109} \mathrm{Cd}$. Water was not changed during the $14 \mathrm{~d}$ exposure period, and ${ }^{109} \mathrm{Cd}$ in the water was determined on Days 0,7 and 14 . Total radioactivity after exposure in the 5 to 7 sea stars from each aquarium is given. Temperature was $15.5^{\circ} \mathrm{C}$ and salinity was $20.5 \%$

\begin{tabular}{|c|c|c|c|c|c|c|c|c|}
\hline \multirow[t]{2}{*}{$\begin{array}{l}\text { Experiment no. } \\
\text { Date }\end{array}$} & \multicolumn{2}{|c|}{$\begin{array}{c}\text { Exposure } \\
\left(\mu \mathrm{g} \mathrm{I}^{-1}\right)\end{array}$} & \multicolumn{3}{|c|}{$\begin{array}{c}{\left[{ }^{109} \mathrm{Cd}\right]} \\
\left(\mathrm{dpm} \mathrm{ml} l^{-1}\right) \\
\text { Day }\end{array}$} & \multirow{2}{*}{$\begin{array}{l}\text { Weight }{ }^{d} \text { and } \\
\text { no. }(n) \text { of } \\
\text { animals } \\
\text { sampled }\end{array}$} & \multirow[t]{2}{*}{$\begin{array}{l}{ }^{109} \mathrm{Cd} \text { in } \\
\text { animals } \\
\text { (dpm) }\end{array}$} & \multirow{2}{*}{$\begin{array}{l}\text { Loss from water } \\
\text { accounted for by } \\
\text { uptake in animals } \\
\left(\% \text { of }{ }^{109} \mathrm{Cd}\right)\end{array}$} \\
\hline & $\mathrm{Cd}$ & $\mathrm{Se}-\mathrm{SeO}_{3}^{--}$ & 0 & 7 & 14 & & & \\
\hline Expt 4 & 0 & 0 & 63 & 60 & 48 & $2.5 \pm 1.6(6)$ & 168405 & 105 \\
\hline \multirow[t]{33}{*}{ 1 Jul 1987} & 0 & 141 & 65 & 37 & 25 & $2.4 \pm 1.8$ & 270370 & 84 \\
\hline & 0.0125 & 0 & 76 & 64 & 46 & $3.4 \pm 1.7$ & 136310 & 57 \\
\hline & 0.0125 & 141 & 66 & 33 & 22 & $3.6 \pm 3.0 \quad(7)$ & 340695 & 97 \\
\hline & 0.025 & 0 & 71 & 59 & 46 & $3.1 \pm 1.1$ & 180945 & 90 \\
\hline & 0.025 & 141 & 70 & 34 & 26 & $2.9 \pm 1.7$ & 377485 & 107 \\
\hline & 0.05 & 0 & 76 & 65 & 52 & $3.3 \pm 2.0 \quad(7)$ & 139195 & 73 \\
\hline & 0.05 & 141 & 71 & 33 & 24 & $3.4 \pm 2.0$ & 376210 & 100 \\
\hline & 0.1 & 0 & 79 & 68 & 60 & $3.9 \pm 2.2(7)$ & 108820 & 72 \\
\hline & 0.1 & 141 & 74 & 36 & 20 & $2.8 \pm 1.5$ & 397585 & 92 \\
\hline & 0.2 & 0 & 74 & 62 & 46 & $2.7 \pm 1.6$ & 114150 & 51 \\
\hline & 0.2 & 141 & 74 & 46 & 29 & $3.1 \pm 1.2$ & 395595 & 110 \\
\hline & 0.4 & 0 & 71 & 64 & 62 & $3.1 \pm 2.2(7)$ & 145400 & 83 \\
\hline & 0.4 & 141 & 75 & 28 & 22 & $2.3 \pm 1.4$ & 444870 & 105 \\
\hline & 0.8 & 0 & 78 & 65 & 54 & $3.0 \pm 1.9(7)$ & 166360 & 87 \\
\hline & 0.8 & 141 & 73 & 33 & 23 & $2.4 \pm 1.0$ & 445640 & 111 \\
\hline & 1.6 & 0 & 75 & 71 & 56 & $2.5 \pm 1.3(7)$ & 119850 & 79 \\
\hline & 1.6 & 141 & 78 & 25 & 20 & $2.4 \pm 1.7 \quad(7)$ & 429455 & 93 \\
\hline & 3.2 & 0 & 79 & 67 & 53 & $3.1 \pm 1.6(7)$ & 154975 & 75 \\
\hline & 3.2 & 141 & 75 & 28 & 19 & $2.3 \pm 1.1$ & 425111 & 95 \\
\hline & 6.3 & 0 & 75 & 70 & 55 & $3.2 \pm 2.2(7)$ & 81120 & 51 \\
\hline & 6.3 & 141 & 73 & 23 & 16 & $3.0 \pm 1.1$ & 281440 & 62 \\
\hline & 12.5 & 0 & 74 & 70 & 62 & $2.7 \pm 1.2(7)$ & 49765 & 52 \\
\hline & 12.5 & 141 & 74 & 42 & 20 & $3.1 \pm 1.3(7)$ & 466060 & 108 \\
\hline & 25 & 0 & 74 & 71 & 62 & $2.7 \pm 0.9$ & 66430 & 69 \\
\hline & 25 & 141 & 74 & 52 & 43 & $3.2 \pm 1.9(7)$ & 153900 & 62 \\
\hline & 50 & 0 & 79 & 75 & 63 & $2.8 \pm 1.7(7)$ & 65220 & 51 \\
\hline & 50 & 141 & 76 & 60 & 46 & $2.7 \pm 1.3$ & 220710 & 92 \\
\hline & 100 & 0 & 78 & 73 & 67 & $3.2 \pm 1.9(7)$ & 43315 & 50 \\
\hline & 100 & 141 & 76 & 67 & 57 & $2.9 \pm 2.0$ & 151795 & 100 \\
\hline & 200 & 0 & 79 & 79 & 72 & $2.4 \pm 1.2(7)$ & 34520 & 62 \\
\hline & 200 & 141 & 78 & 69 & 54 & $3.5 \pm 2.1$ & 94650 & 50 \\
\hline & 400 & 0 & 78 & 75 & 71 & $3.5 \pm 2.0$ & 31010 & 55 \\
\hline & 400 & 141 & 80 & 72 & 57 & $3.7 \pm 2.1$ & 91570 & 50 \\
\hline Expt 5 & b & 0 & 74 & 50 & 35 & $5.4 \pm 2.4$ & 189725 & 61 \\
\hline \multirow[t]{9}{*}{1 Aug 1987} & $\mathrm{~b}$ & 0.25 & 78 & 55 & 37 & $5.8 \pm 2.3(7)$ & 184859 & 56 \\
\hline & $\mathrm{b}$ & 0.50 & 76 & 52 & 37 & $5.7 \pm 3.2(7)$ & 168155 & 54 \\
\hline & $b$ & 1 & 74 & 56 & 41 & $4.9 \pm 2.3(7)$ & 142290 & 54 \\
\hline & $\mathrm{b}$ & 2 & 78 & 54 & 43 & $4.2 \pm 2.2$ & 164815 & 59 \\
\hline & $b$ & 4 & 78 & 56 & 39 & $5.3 \pm 1.6(7)$ & 164695 & 53 \\
\hline & $b$ & 8 & 77 & 52 & 34 & $5.9 \pm 2.4$ & 190870 & 56 \\
\hline & b & 16 & 72 & 55 & 40 & $5.0 \pm 1.9$ & 186220 & 73 \\
\hline & $b$ & 32 & 78 & 49 & 33 & $5.5 \pm 1.5$ & 225705 & 63 \\
\hline & $\mathrm{b}$ & 64 & 75 & 53 & 37 & $5.2 \pm 2.0$ & 213670 & 70 \\
\hline Expt 6 & b & 0 & 65 & 55 & 49 & $3.4 \pm 1.8(7)$ & 94905 & 91 \\
\hline \multirow[t]{7}{*}{22 Sep 1987} & b & 25 & 64 & 61 & 53 & $2.9 \pm 1.3(7)$ & 100610 & 125 \\
\hline & b & 50 & 69 & 50 & 44 & $3.2 \pm 1.1(7)$ & 155290 & 72 \\
\hline & $\mathrm{b}$ & 75 & 67 & 56 & 47 & $3.6 \pm 0.8$ & 147890 & 92 \\
\hline & b & 100 & 69 & 54 & 42 & $4.0 \pm 1.3$ & 220185 & 101 \\
\hline & $b$ & 125 & 65 & 47 & 30 & $3.4 \pm 1.4(7)$ & 196220 & 70 \\
\hline & b & 150 & 69 & 32 & 21 & $3.0 \pm 1.8(7)$ & 325615 & 85 \\
\hline & b & 200 & 63 & 15 & $16^{\mathrm{c}}$ & $2.4 \pm 0.8$ & 285920 & 76 \\
\hline
\end{tabular}


electron capture detector and a $2000 \mathrm{~mm} \times 2 \mathrm{~mm}$ glass column packed with $10 \%$ SE-30 and acid-washed dimethyldichlorosilan-treated chromosorb W 100/120. Oven temperature was $200^{\circ} \mathrm{C}$. The selenium concentration in an NBS oyster standard with a certified selenium concentration of $2.1 \pm 0.5 \mathrm{~kg}$ Se $\mathrm{g}^{-1}$ was found to be 2.05 and $2.17 \mu \mathrm{g} \mathrm{Se} \mathrm{g}^{-1}$ in duplicate measurements. Determinations of selenium concentrations in 6 replicate samples of pyloric caeca from selenite exposed sea stars resulted in a standard deviation of $4.2 \%$. Selenite concentrations in the seawater were determined with a Perkin-Elmer MHS-20 hydride generating system.

Cadmium analysis. Tissue samples were freeze dried, weighed and dissolved in 2 to $3 \mathrm{ml}$ concentrated nitric acid at $120^{\circ} \mathrm{C}$ to obtain a clear yellow solution. The samples were evaporated almost to dryness, then $200 \mu 30 \% \mathrm{H}_{2} \mathrm{O}_{2}$ was cautiously added. Thereafter the samples were evaporated to dryness and redissolved in $10.0 \mathrm{ml} 0.2 \%$ nitric acid. The cadmium concentration in the solution resulting from this procedure was determined on a Perkin-Elmer 2380 atomic absorption spectrophotometer. Air-acetylene flame and deuterium background correction were used. An NBS oyster standard with a certified cadmium concentration of $3.5 \pm$ $0.4 \mu \mathrm{g} \mathrm{Cd} \mathrm{g}^{-1}$ dry wt was found to contain 3.1 and 3.2 $\mu \mathrm{g} \mathrm{Cd} \mathrm{g^{-1 }}$ dry wt (duplicate determinations).

Radioactivity measurements. Radioactive cadmium $\left({ }^{109} \mathrm{Cd}\right)$ was obtained from New England Nuclear and radioactivity was measured with a Searle Mark III Liquid Scintillation Counter. Tissue samples were dissolved in Lumasolve prior to determination of ${ }^{109} \mathrm{Cd}$ content. Radioactivity is given as disintegrations per minute (dpm).

Statistical treatment of data. Two-tailed student's $t$ tests and regression analysis were used in statistical evaluation of the data (Sokal \& Rohlf 1969).

Experiments. The 4 experimental species were exposed to $200 \mu \mathrm{g} \mathrm{Cd} \mathrm{l}^{-1}(1.78 \mu \mathrm{M})$ alone and $200 \mu \mathrm{g} \mathrm{Cd}$ $1^{-1}$ plus an equimolar selenite concentration (141 $\mu \mathrm{g} \mathrm{Se}$ $\mathrm{SeO}_{3}^{--} 1^{-1}$ ) for ca 1 mo (Expts 1, 7,8 and 9; Table 1). An additional group of mussels was exposed to $200 \mu \mathrm{g} \mathrm{Cd}$ $1^{-1}$ and a 5 -fold molar selenite concentration (Expt 7 ; Table 1).

Marked effects of selenite on cadmium uptake were noted in Asterias rubens, and additional experiments (Expts 2 to 6) were carried out with this species. In Expt 2 , the effect of varying selenite concentrations on cadmium uptake (from $200 \mu \mathrm{g} \mathrm{Cd} \mathrm{I}^{-1}$ ) was assessed and in Expt 3 it was investigated whether cadmium affected selenium uptake (Table 1). In Expt 4 the effect of selenite on cadmium uptake was investigated at cadmium concentrations ranging from background levels to $400 \mu \mathrm{g} \mathrm{Cd} \mathrm{I}^{-1}$ and in Expts 5 and 6 the effects of different selenite concentrations on uptake of ${ }^{109} \mathrm{Cd}$ from background concentrations were investigated (Table 2). Background levels of cadmium and selenium in $A$. rubens were determined.

\section{RESULTS}

\section{Experiment 1}

Background levels of selenium and cadmium in Asterias rubens from Lillebæelt are shown in Table 3.

Sea stars exposed to $200 \mu \mathrm{g} \mathrm{Cd} \mathrm{l}^{-1}$ took up cadmium in tube feet and pyloric caeca at a rate of ca $1.2 \mu \mathrm{g} \mathrm{Cd}$ $\mathrm{g}^{-1}$ dry wt $\mathrm{d}^{-1}$ during the first $10 \mathrm{~d}$, when steady state

Table 3. Asterias rubens. Background selenium and cadmium concentrations $\left(\mu \mathrm{g} \mathrm{g}^{-1}\right.$ dry wt $\left.\pm \mathrm{SD}\right)$ in 40 to $50 \mathrm{~g}$ sea stars from Lillebælt

\begin{tabular}{|ccccc} 
& $\begin{array}{c}\text { Pyloric } \\
\text { caeca }\end{array}$ & $\begin{array}{c}\text { Body } \\
\text { wall }\end{array}$ & $\begin{array}{c}\text { Tube } \\
\text { feet }\end{array}$ & $n$ \\
\hline$\mu \mathrm{g} \mathrm{Se} \mathrm{g}^{-1}$ & $3.4 \pm 0.7$ & $0.85 \pm 0.03$ & $1.62 \pm 0.23$ & 7 \\
$\mu \mathrm{g} \mathrm{Cd} \mathrm{g}^{-1}$ & $0.18 \pm 0.06$ & $0.48 \pm 0.21$ & $0.26 \pm 0.07$ & 5 \\
\hline
\end{tabular}

concentrations of 10 to $12 \mu \mathrm{g} \mathrm{Cd} \mathrm{g}^{-1}$ were reached (Fig 1a). Uptake in the body wall proceeded at a slightly higher rate and a steady state concentration of 20 to $25 \mu \mathrm{g} \mathrm{Cd} \mathrm{g}^{-1}$ was reached after $2 \mathrm{wk}$ (Fig. 1a).

Sea stars exposed to $200 \mu \mathrm{g} \mathrm{Cd}+141 \mu \mathrm{g} \mathrm{Se}-\mathrm{SeO}_{3}^{--}$ $1^{-1}$ took up cadmium in body wall and pyloric caeca at a rate of $5 \mu \mathrm{g} \mathrm{Cd} \mathrm{g}^{-1} \mathrm{~d}^{-1}$ and in tube feet at a rate of $10 \mu \mathrm{g}$ $\mathrm{Cd} \mathrm{g}^{-1} \mathrm{~d}^{-1}$ (Fig. 1b). Uptake proceeded linearly over $4 \mathrm{wk}$, and no trend toward a steady state level was observed. Differences between cadmium concentrations in selenite and non-selenite exposed groups were statistically significant $(p<0.01)$ for all tissues and sampling times.

Selenium was taken up in sea stars exposed to selenite and cadmium at rates of 2.2,2.9, and $5.2 \mu \mathrm{g} \mathrm{Se} \mathrm{g}$ dry wt $\mathrm{d}^{-1}$ in body wall, pyloric caeca, and tube feet, respectively (Fig. 1c). No trend toward steady state levels was observed during $4 \mathrm{wk}$.

$\mathrm{Cd}$ : Se molar ratios in the tissues of sea stars exposed to selenite + cadmium increased for the first $2 \mathrm{wk}$, reaching steady state levels of ca 1.1, 1.2, and 1.8 in pyloric caeca, tube feet, and body wall, respectively (Fig. 1d)

\section{Experiment 2}

All of the sea stars exposed to selenite concentrations of 562 to $4496 \mu \mathrm{g} \mathrm{Se}-\mathrm{SeO}_{3}^{--} 1^{-1}$ died during the experiment. This may be due to the toxicity of selenite, but the overall mortality in this experiment was consider- 

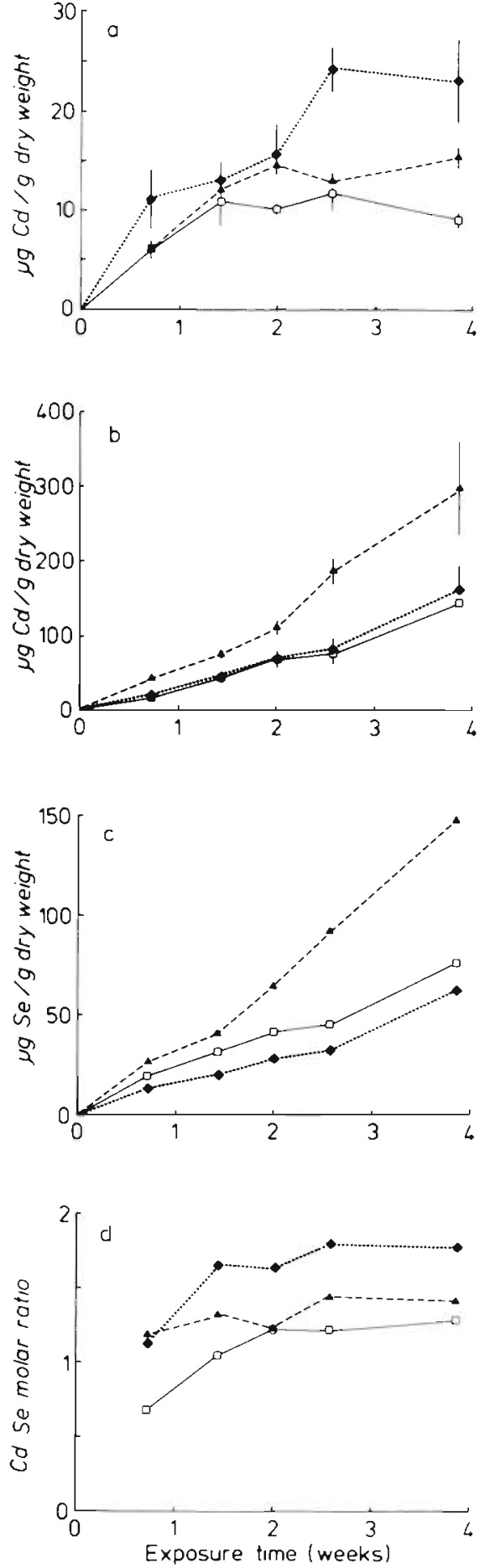

Fig. 1. Asterias rubens. (a) Cadmium concentrations in tissues of sea stars exposed to $200 \mu \mathrm{g} \mathrm{Cd} \mathrm{l^{-1 }}$ (b) Cadmium concentrations in tissues of sea stars exposed to $200 \mu \mathrm{g} \mathrm{Cd}+141 \mu \mathrm{g}$ $\mathrm{Se}-\mathrm{SeO}_{3}^{--} 1^{-1}$. (c) Selenium concentrations in tissues of sea stars exposed to $200 \mu \mathrm{g} \mathrm{Cd}+141 \mu \mathrm{g} \mathrm{Se}-\mathrm{SeO}_{3}^{--} 1^{-1}$ (d) $\mathrm{Cd}: \mathrm{Se}$ molar ratios in tissues of sea stars exposed to $200 \mu \mathrm{g} \mathrm{Cd}+141$ $\mu \mathrm{g} \mathrm{Se}-\mathrm{SeO}_{3}^{--} 1^{-1}$. (4) Tube feet; (c) pyloric caeca; ( $\bullet$ body wall. Mean \pm SEM shown in (a) and (b). Selenium was determined in samples pooled from individuals. Numbers of animals can be seen in Table 1 able (Table 1), probably a result of damage from the seines in which the sea stars were caught. In spite of the mortality in this experiment, cadmium uptake in individuals exposed to $200 \mu \mathrm{g} \mathrm{Cd}+141 \mu \mathrm{g} \mathrm{Se}-\mathrm{SeO}_{3}^{--}$ was comparable to uptake after 3 wk in Expt 1.

Cadmium uptake in body wall, tube feet and pyloric caeca was augmented by $17.6,17.6$, and $70 \mu \mathrm{g}$ Se$\mathrm{SeO}_{3}^{--} 1^{-1}$, respectively (Fig. 2a), while lower selenite
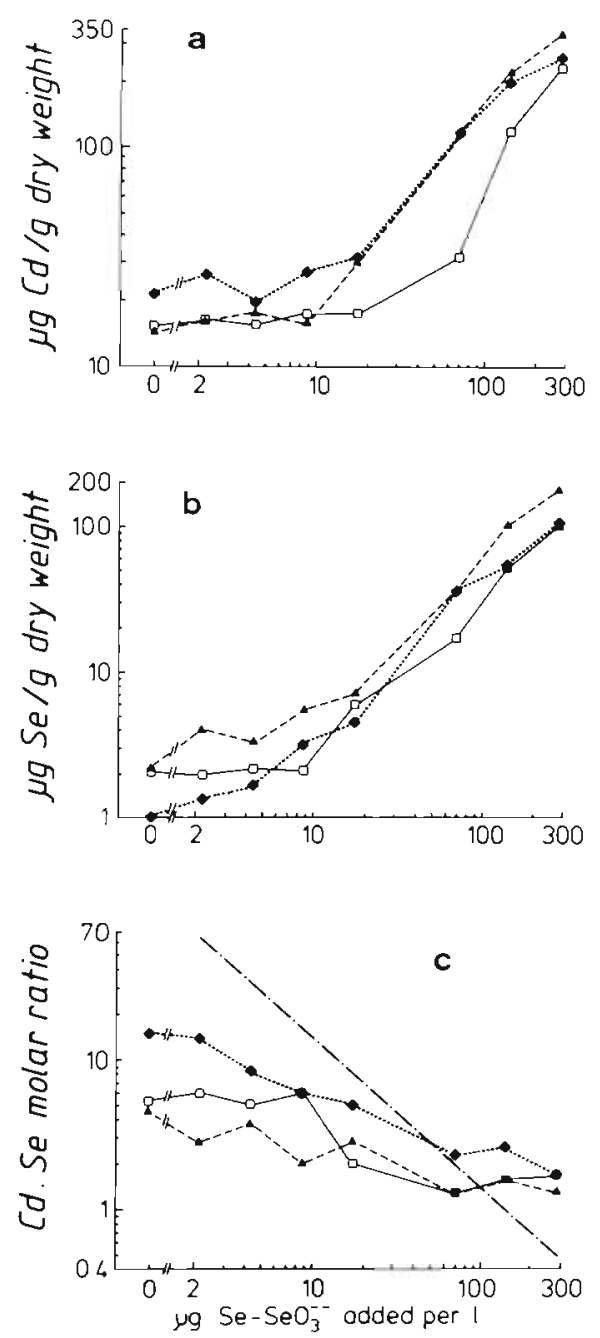

Fig. 2. Asterias rubens. (a) Cadmium concentrations, (b) selenium concentrations and (c) Cd:Se molar ratios in tissues of sea stars exposed to $200 \mu \mathrm{g} \mathrm{Cd} \mathrm{l}^{-1}$ and different selenite concentrations for $21 \mathrm{~d}$. Results from analysis of samples pooled from individuals in each group are shown. (-...) in (c):

$\mathrm{Cd}$ :Se molar ratio in seawater Symbols as in Fig. 1

concentration had no or only marginal effects on cadmium uptake over $3 \mathrm{wk}$.

Exposure to all of the selenite concentrations seemed to augment selenium concentrations in tube feet and body wall (Fig. 2b), whereas selenium concentrations in pyloric caeca were augmented only by exposure to 
selenite concentrations above $10 \mu \mathrm{g} \mathrm{Se}-\mathrm{SeO}_{3}^{--} \mathrm{l}^{-1}$ (Fig. $2 b)$. Selenium concentrations in the pyloric caeca of sea stars exposed to $200 \mu \mathrm{g} \mathrm{Cd} \mathrm{l}^{-1}$ for $2 \mathrm{wk}$ seemed somewhat low compared with unexposed individuals (Fig. 2b; Table 3).

$\mathrm{Cd}$ :Se ratios in the tissues decreased as the ambient selenite concentration increased (Fig. 2c). The changes in Cd:Se molar ratios in the tissues as the selenite concentration increased were much smaller than the changes in the water phase (Fig. 2c).

\section{Experiment 3}

Exposure to $200 \mu \mathrm{g} \mathrm{Cd} \mathrm{^{-1 }}$ did not consistently affect the uptake of selenium from $141 \mu \mathrm{g} \mathrm{Se}-\mathrm{SeO}_{3}^{--} \mathrm{l}^{-1}$ (Fig. $3 a, b)$. At Day 17, the selenium concentration in the body wall of the 2 groups showed a statistically significant difference ( $p=0.039)$, but for the other tissues and sampling days no differences were observed. After $1 \mathrm{wk}$ selenium was taken up linearly with time at rates of $1.4,1.7$, and $2.0 \mu \mathrm{g} \mathrm{Se} \mathrm{g}^{-1}$ dry wt $\mathrm{d}^{-1}$ in body wall, pyloric caeca and tube feet, respectively (Fig. 3a, b). In the selenium + cadmium exposed group, cadmium was taken up linearly with time at rates of 2.9, 3.5, and $7.0 \mu \mathrm{g} \mathrm{Cd} \mathrm{g}^{-1}$ dry wt $\mathrm{d}^{-1}$ (Fig. 3c). During the experiment $\mathrm{Cd}$ :Se ratios approached 1 and 1.2 in pyloric caeaca and body wall, respectively, while the Cd:Se molar ratio in tube feet increased from 1.3 to 2.2 during the 4 wk (Fig. 3d).

Cadmium and selenium uptake was lower in this winter experiment compared with the 2 summer experiments (Expts 1 and 2).

\section{Experiments 4, 5 and 6}

Generally, 50 to $100 \%$ of the decrease in the ${ }^{109} \mathrm{Cd}$ concentration in the water phase could be accounted for by uptake by the sea stars (Table 2).

In Expt 6, sea stars exposed to $200 \mu \mathrm{g} \mathrm{Se}-\mathrm{SeO}_{3}^{--} \mathrm{l}^{-1}$ were in such poor condition after $9 \mathrm{~d}$ exposure that the remaining 5 specimens were analysed for ${ }^{109} \mathrm{Cd}$ on that day.

In the groups exposed to radioactive cadmium alone the concentration factors for ${ }^{109} \mathrm{Cd}$ in whole sea stars were $1127 \pm 541$ (Expt 4; Fig. 4), $829 \pm 328$ (Expt 5; Fig. 5), and $809 \pm 380$ (Expt 6; Fig. 5). Sea stars exposed to stable cadmium concentrations between 0.0125 and $3.2 \mu \mathrm{g} \mathrm{Cd} \mathrm{l} \mathrm{Cl}^{-1}$ had concentration factors in the range 600 to 900 , and although the concentration factors in 3 of these groups were significantly lower than in the control group of the experiment, no decreasing trend was seen for this range of stable cadmium concentrations (Fig. 4). Concentration factors
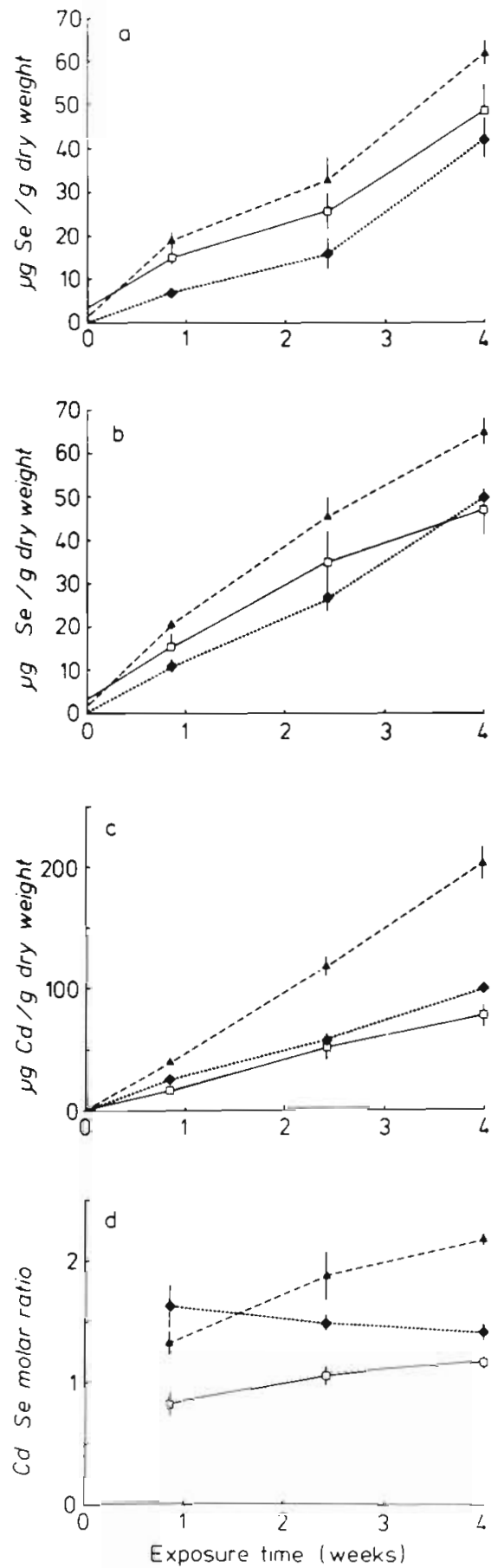

Fig. 3. Asterias rubens. (a) Selenium concentrations in tissues of sea stars exposed to $141 \mu \mathrm{g} \mathrm{Se}-\mathrm{SeO}_{3}^{-} \mathrm{l}^{-1}$ (b) Selenium concentrations in tissues of sea stars exposed to $141 \mu \mathrm{g} \mathrm{Se-}$ $\mathrm{SeO}_{3}^{--}+200 \mu \mathrm{g} \mathrm{Cd} \mathrm{l}^{-1}$ (c) Cadmium concentrations in tissues of sea stars exposed to $141 \mu \mathrm{g} \mathrm{Se}-\mathrm{SeO}_{3}^{--}+200 \mu \mathrm{g} \mathrm{Cd} \mathrm{l^{-1 }}$ (d) $\mathrm{Cd}$ :Se molar ratios in tissues of sea stars exposed to $141 \mu \mathrm{g} \mathrm{Se}-$ $\mathrm{SeO}_{3}^{--}+200$ ug Cd l-1 Symbols as in Fig. 1

for sea stars exposed to higher stable cadmium concentrations decreased from 710 at $3.2 \mu \mathrm{g} \mathrm{Cd}^{-1}$ to ca $130 \mathrm{at}$ 200 and $400 \mu \mathrm{g} \mathrm{Cd}^{-1}$ (Fig. 4). 


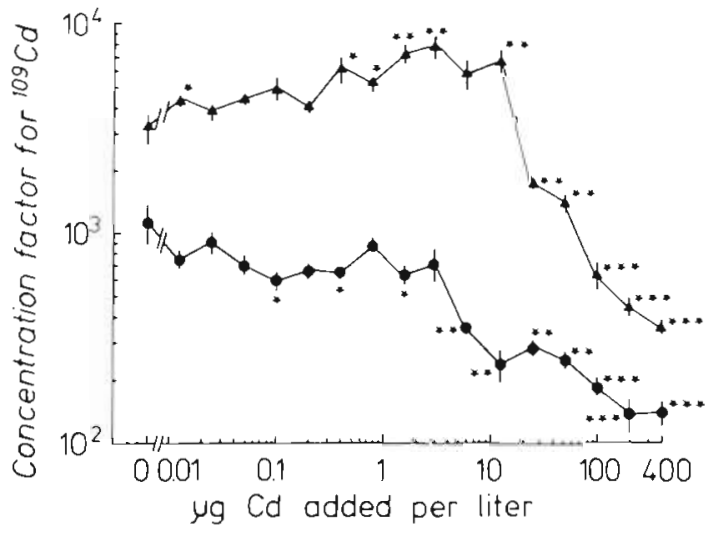

Fig. 4. Asterias rubens. Concentration factor $\left(\mathrm{dpm} \mathrm{g} \mathrm{g}^{-1}\right.$ dry wt tissue $\div \mathrm{dpm} \mathrm{ml} \mathrm{m}^{-1}$ seawater) for ${ }^{109} \mathrm{Cd}$ in sea stars after exposure to different concentrations of stable cadmium for 14 d. With (4) and without ( $\bullet$ ) addition of $141 \mu \mathrm{g} \mathrm{Se}-\mathrm{SeO}_{3}^{--} \mathrm{l}^{-1}$. Means \pm SEM are shown. Numbers of individuals are given in Table 2. ${ }^{\prime} \cdot \cdots$ and $\cdots$ indicate that the difference from the control group in each series is statistically significant at the $0.05,0.01$ and 0.001 level, respectively

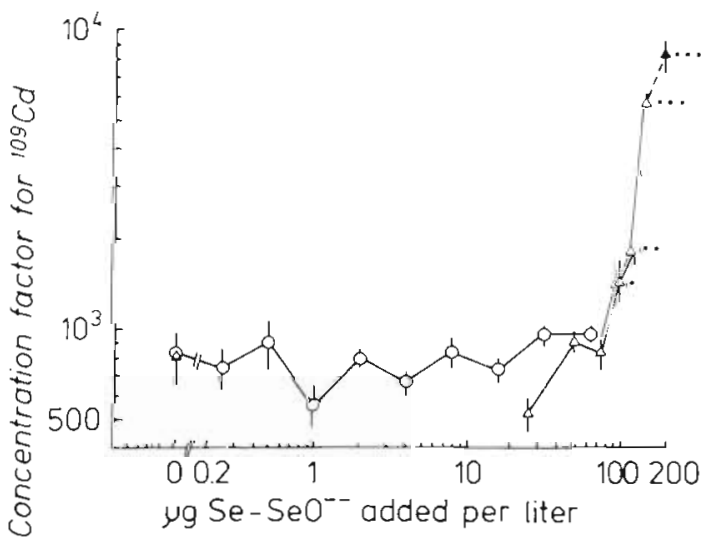

Fig. 5. Asterias rubens. Concentration factor (dpm g ${ }^{-1} \mathrm{dry}$ wt tissue $\div$ dpm $\mathrm{ml}^{-1}$ seawater) for ${ }^{109} \mathrm{Cd}$ in sea stars after exposure to different selenite concentrations for $14 \mathrm{~d}$. (o) Expt 5; $(\triangle)$ Expt 6 ( 4 : exposed for $9 \mathrm{~d}$ only). Means \pm SEM are shown. Numbers of individuals are given in Table $2 .^{\circ}, \cdots$ and - indicate that the difference from the non-selenite exposed group is statistically significant at the $0.05,0.01$ and 0.001 . level, respectively

Exposure to 0.25 to $75 \mu \mathrm{g} \mathrm{Se-SeO}{ }^{--} 1^{-1}$ for $2 \mathrm{wk}$ did not affect ${ }^{109} \mathrm{Cd}$-concentration factors in the sea stars (Fig. 5), while selenium concentrations at and above $100 \mu \mathrm{g} \mathrm{Se}-\mathrm{SeO}_{3}^{--} 1^{-1}$ significantly augmented ${ }^{109} \mathrm{Cd}$ concentration factors (Fig. 5).

In the groups exposed to $141 \mu \mathrm{g} \mathrm{Se}-\mathrm{SeO}_{3}^{--} \mathrm{l}^{-1}$, the concentration factor for ${ }^{109} \mathrm{Cd}$ increased from 3300 to 7800 with from 0 to $3.2 \mu \mathrm{g} \mathrm{Cd}$ added $\mathrm{l}^{-1}$ (Fig. 4). In this interval of stable cadmium concentrations the correlation between concentration factors and cadmium concentrations was highly significant (log concentration factor $=3.78+0.148 \log \mu \mathrm{g} \mathrm{Cd}$ added $\mathrm{I}^{-1}, r^{2}=0.4179$, $n=68 ; p<0.001)$. For cadmium concentrations above
$12.5 \mu \mathrm{g} \mathrm{Cd} l^{-1}$, concentration factors for ${ }^{109} \mathrm{Cd}$ decreased considerably, reaching concentration factors of 350 at $400 \mu \mathrm{g} \mathrm{Cd}{ }^{-1}$.

\section{Experiment 7}

Uptake of cadmium by Mytilus edulis reduced cadmium concentrations in the seawater from $200 \mu \mathrm{g} \mathrm{Cd}$ $\mathrm{l}^{-1}$ to between 80 and $120 \mu \mathrm{g} \mathrm{Cd} \mathrm{l^{-1 }}$ in the period between successive water changes.

Mytilus edulis exposed to $200 \mu \mathrm{g} \mathrm{Cd} \mathrm{l^{-1 }}$ alone for 4 wk took up cadmium in mantle, digestive gland, foot and adductor muscle linearly with time at rates of $9.3,36,7.7$, and $6.4 \mu \mathrm{g} \mathrm{Cd} \mathrm{g}{ }^{-1}$ dry wt $\mathrm{d}^{-1}$, respectively (Fig. 6). In gills and shell, cadmium was taken up at an

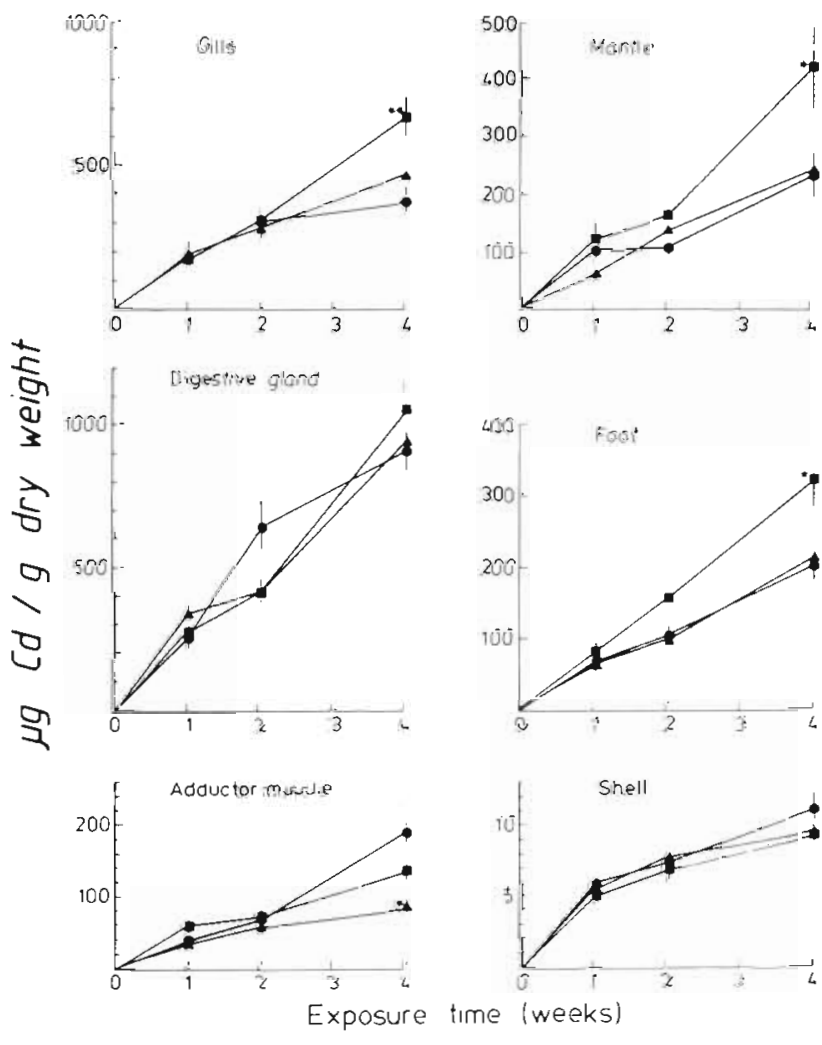

Fig. 6. Mytilus edulis. Concentrations of cadmium in tissues of mussels exposed to (•) $200 \mu \mathrm{g} \mathrm{Cd} \mathrm{l^{-1 }}$, (4) $200 \mu \mathrm{g} \mathrm{Cd}+141 \mu \mathrm{g}$ $\mathrm{Se}_{-} \mathrm{SeO}_{3}^{--} \mathrm{l}^{-1}$, and (a) $200 \mu \mathrm{g} \mathrm{Cd}+703 \mu \mathrm{g} \mathrm{Se}-\mathrm{SeO}_{3}^{--} \mathrm{l}^{-1}$ Means \pm SEM are shown. Numbers of individuals are given in Table 1. ' and ' indicate that difference between the selenite and non-selenite exposed group is statistically significant at the 0.05 and 0.01 level, respectively

initial rate of 24 and $0.8 \mu \mathrm{g} \mathrm{Cd} \mathrm{g}^{-1}$ dry wt $\mathrm{d}^{-1}$ for 1 to $2 \mathrm{wk}$ after which time uptake rates decreased. Concurrent exposure to $141 \mu \mathrm{g} \mathrm{Se}-\mathrm{SeO}_{3}^{--} \mathrm{l}^{-1}$ only affected cadmium uptake in the adductor muscle which contained less cadmium after $4 \mathrm{wk}$ than the group exposed to cadmium alone (Fig. 6). Concurrent exposure to $703 \mu \mathrm{g} \mathrm{Se}-\mathrm{SeO}_{3}^{--} 1^{-1}$ did not affect cadmium uptake in 
digestive gland, shell, and adductor muscle, whereas mantle and foot took up cadmium linearly with time at rates 1.6 and 1.5 times higher than in the group exposed to cadmium alone (Fig. 6). In gills, the initial cadmium uptake rate was not affected by $703 \mu \mathrm{g} \mathrm{Se}-$ $\mathrm{SeO}_{3}^{--} 1^{-1}$, but uptake proceeded linearly over $4 \mathrm{wk}$, leading to increased cadmium concentration relative to the group exposed to cadmium alone (Fig. 6).

\section{Experiment 8}

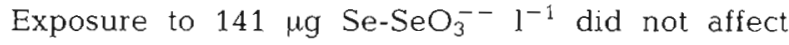
uptake of cadmium from $200 \mu \mathrm{g} \mathrm{Cd} \mathrm{l^{-1 }}$ in Littorina littorea (Fig. 7). Uptake in soft parts proceeded linearly

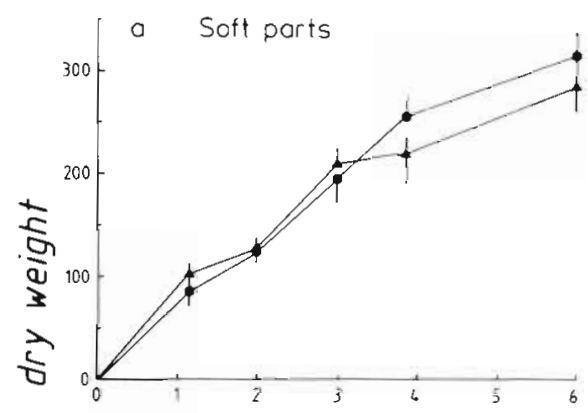

on

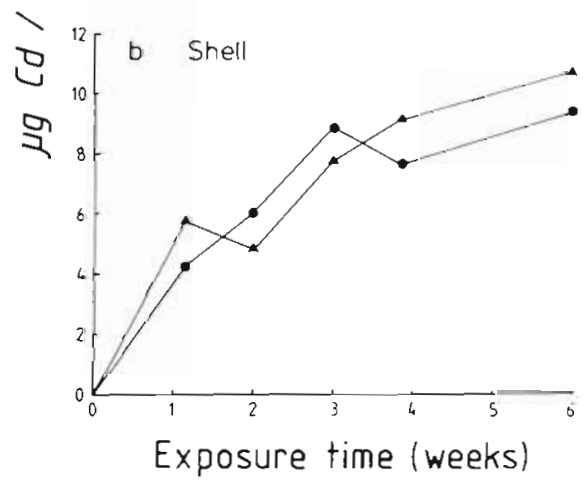

Fig. 7 Littorina littorea. Concentrations of cadmium in (a) soft parts and (b) shells of periwinkles exposed to $\left(\bullet 200 \mu \mathrm{g} \mathrm{Cd}{ }^{-1}\right.$, (A) $200 \mu \mathrm{g} \mathrm{Cd}+141 \mu \mathrm{g} \mathrm{Se}-\mathrm{SeO}_{3}^{--} 1^{-1}$ For soft parts means \pm SEM for 10 individuals are shown. For shells one determination on a pooled sample from the 10 individuals was carried out

with time at a rate of $11 \mu \mathrm{g} \mathrm{Cd} \mathrm{g}{ }^{-1}$ dry wt d $\mathrm{d}^{-1}$ for 3 to 4 $w k_{i}$ thereafter the uptake rate levelled off (Fig. $7 a$ ). The uptake rate in the shell was $0.6 \mu \mathrm{g} \mathrm{Cd} \mathrm{g^{-1 }}$ dry wt $\mathrm{d}^{-1}$ for $1 \mathrm{wk}$; thereafter the uptake rate levelled off (Fig, 7b).

\section{Experiment 9}

Exposure to $141 \mu \mathrm{g} \mathrm{Se-SeO}{ }_{3}^{--} 1^{-1}$ did not affect uptake of cadmium from $200 \mu \mathrm{g} \mathrm{Cd} \mathrm{^{-1 }}$ in Arenicola marina (Fig. 8). Cadmium was taken up in the body wall linearly with time over $4 \mathrm{wk}$ at a rate of $6.1 \mu \mathrm{g} \mathrm{Cd}$ $\mathrm{g}^{-1}$ dry wt $\mathrm{d}^{-1}$ (Fig. 8a). In the gut, the uptake rate over the first 3 wk was $10.4 \mu \mathrm{g} \mathrm{Cd} \mathrm{g}{ }^{-1}$ dry wt $\mathrm{d}^{-1}$; a trend toward an increased uptake rate late in the experiment
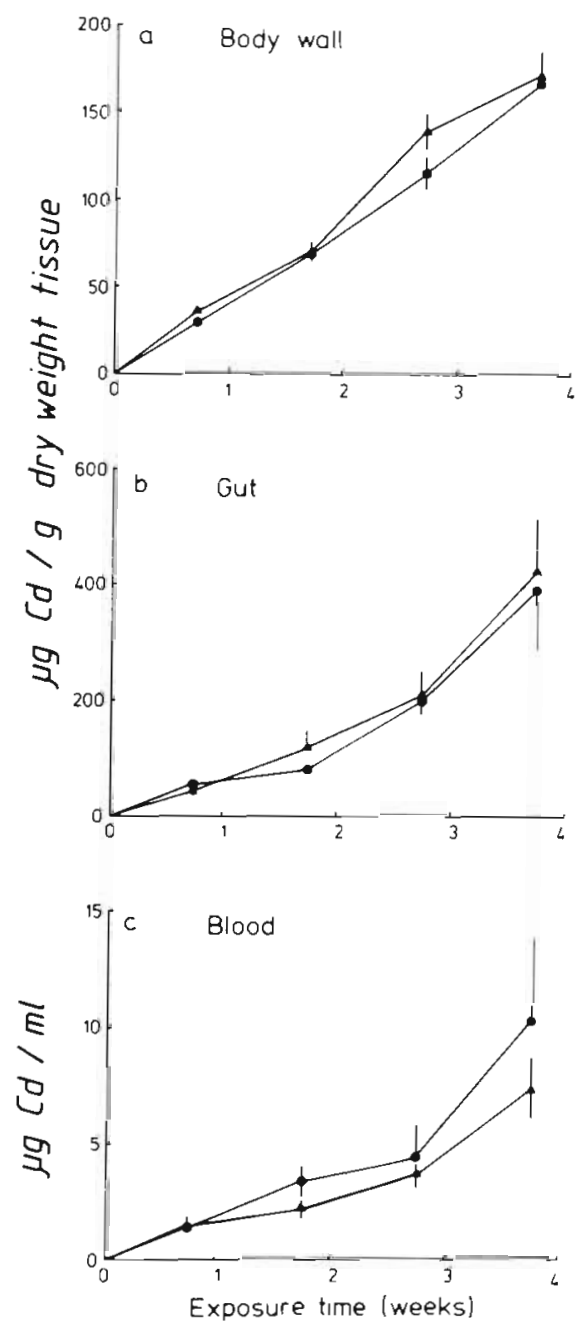

Fig. 8. Arenicola marina. Concentrations of cadmium in (a) body wall, (b) gut, and (c) blood of lugworms exposed to ( $200 \mu \mathrm{g} \mathrm{Cd} \mathrm{]^{-1 }}$ and (4) $200 \mu \mathrm{g} \mathrm{Cd}+141 \mu \mathrm{g} \mathrm{Se}-\mathrm{SeO}_{3}^{--} 1^{-1}$ Means \pm SEM are shown. Numbers of individuals are given in Table 1

was observed (Fig. 8b). The same trend was seen in the blood where the uptake rate during the first 3 wk was $0.23 \mu \mathrm{g} \mathrm{Cd} \mathrm{ml}^{-1} \mathrm{~d}^{-1}$ (Fig. 8c).

\section{DISCUSSION}

\section{Cadmium uptake}

The rate at which cadmium is taken up by Mytilus edulis increases with decreasing salinity (George et al. 
1977, Jackim et al. 1977, Fischer 1986) and increasing amounts of algae filtered (Janssen \& Scholz 1979, Köhler \& Riisgaard 1982, Borchardt 1983). Although temperature does not affect cadmium accumulation in Mytilus spp. (Fowler \& Benayoun 1974, Jackim et al. 1977), uptake rates may depend on season (Jackim et al. 1977). Concentration factors for cadmium decrease with increasing cadmium concentrations (Amiard et al. 1986, Risgaard et al. 1987).

Cadmium uptake rates reported for Mytilus edulis exposed to 100 and $200 \mu \mathrm{g} \mathrm{Cd} \mathrm{l}^{-1}$ in the laboratory show large variations (Table 4), and the present results are within the range reported earlier. The cadmium uptake rate in Littorina littorea reported by Langston \& Zhou (1987) appears very low compared with that reported by Amiard et al. (1987) and the results of the present work (Table 5). Langston \& Zhou (1987), however, exposed the periwinkles in tidal tanks, and as the degree of accumulation is related to the immersion time (Langston \& Zhou 1987), the difference in uptake

Table 4. Mytilus edulis. Cadmium uptake rates in soft parts of mussels exposed to 100 and $200 \mu \mathrm{g} \mathrm{Cd} \mathrm{l^{-1 }}$ Uptake rates have been calculated in the initial exposure period, where cadmium is taken up linearly with time. For semi-static exposure the intervals between water changes are given

\begin{tabular}{|c|c|c|c|c|c|c|c|c|c|}
\hline Tissue & $\begin{array}{c}\begin{array}{c}\text { Cadmium uptake } \\
\text { rate }\end{array} \\
\left(\frac{\mu g \mathrm{Cd} \mathrm{g}^{-1} \mathrm{dry}_{\mathrm{wt} \mathrm{d}}^{-1}}{\mu \mathrm{g} \mathrm{Cd} \mathrm{\textrm {ml } ^ { - 1 }}}\right)\end{array}$ & $\begin{array}{c}\text { Exposure } \\
\text { concen- } \\
\text { tration } \\
(\mu \mathrm{g} \mathrm{Cd} \\
\left.\mathrm{ml}^{-1}\right)\end{array}$ & $\begin{array}{l}\text { Shell } \\
\text { length } \\
(\mathrm{mm})\end{array}$ & $\begin{array}{c}\text { Salinity } \\
(\% \infty)\end{array}$ & $\begin{array}{c}\text { Temper- } \\
\text { ature } \\
\left({ }^{\circ} \mathrm{C}\right)\end{array}$ & $\begin{array}{l}\text { Exposure } \\
\text { system }\end{array}$ & $\begin{array}{l}\text { Time } \\
\text { of year }\end{array}$ & Fed & Source \\
\hline Gills & 46 & \multirow[t]{6}{*}{$200^{a}$} & \multirow[t]{6}{*}{ - } & \multirow[t]{6}{*}{35} & \multirow[t]{6}{*}{15.5} & \multirow{6}{*}{$\begin{array}{l}\text { Semi-static } \\
1 \mathrm{~d}\end{array}$} & \multirow[t]{6}{*}{ Winter } & \multirow[t]{6}{*}{ No } & \multirow{6}{*}{$\begin{array}{l}\text { Amiard et al. } \\
(1987)\end{array}$} \\
\hline Viscera & 36 & & & & & & & & \\
\hline Rest & 24 & & & & & & & & \\
\hline Gills & 87 & & & & & & & & \\
\hline Viscera & 44 & & & & & & & & \\
\hline Rest & 29 & & & & & & & & \\
\hline Total & 94 & 100 & $15-18$ & 29 & 18 & Flow & Jun & Yes & $\begin{array}{l}\text { Poulsen et al. } \\
\text { (1982) }\end{array}$ \\
\hline Total & 21 (33) & \multirow[t]{4}{*}{200} & \multirow[t]{4}{*}{$50-70$} & \multirow[t]{4}{*}{27} & \multirow[t]{4}{*}{5} & \multirow{4}{*}{$\begin{array}{l}\text { Semi-static } \\
3 \mathrm{~d}\end{array}$} & \multirow[t]{4}{*}{ Jun } & \multirow[t]{4}{*}{ No (yes) } & \multirow{4}{*}{$\begin{array}{l}\text { Köhler \& Riis- } \\
\text { gaard (1982) }\end{array}$} \\
\hline Mantle & $24(37)$ & & & & & & & & \\
\hline Muscle & $9(12)$ & & & & & & & & \\
\hline Rest & $28(42)$ & & & & & & & & \\
\hline Total & $74(166)$ & \multirow[t]{7}{*}{100} & \multirow[t]{7}{*}{$60 \quad(42)$} & \multirow[t]{7}{*}{25} & \multirow[t]{7}{*}{10} & \multirow{7}{*}{$\begin{array}{l}\text { Semi-static } \\
2 \mathrm{~d}\end{array}$} & \multirow[t]{7}{*}{ Oct } & \multirow[t]{7}{*}{ No (yes) } & \multirow{7}{*}{$\begin{array}{l}\text { Janssen \& } \\
\text { Scholz (1979) }\end{array}$} \\
\hline Midgut gland & $158(252)$ & & & & & & & & \\
\hline Gills & $81(216)$ & & & & & & & & \\
\hline Mantle & $28(126)$ & & & & & & & & \\
\hline Foot & $25 \quad(46)$ & & & & & & & & \\
\hline Add. muscle & $49 \quad(88)$ & & & & & & & & \\
\hline Kidney & $79(172)$ & & & & & & & & \\
\hline Total & 128 & 200 & 30 & \multirow[t]{2}{*}{17} & \multirow[t]{2}{*}{-} & Flow & Jun & No & Riisgaard et al. \\
\hline Total & 231 & 100 & 27 & & & & & & $(1987)$ \\
\hline Total & 740 & 100 & $\mathrm{~b}$ & 17 & 10 & Semi-static & - & No & George et al. \\
\hline Total & 514 & & & 23 & & $3 \mathrm{~d}$ & & & $(1977)$ \\
\hline Total & 407 & & & $28 / 33$ & & & & & \\
\hline Total & 38 & 200 & $50-70$ & 33 & 13 & Semi-static & - & No & George \& \\
\hline Mantle & 16 & & & & & $4 \mathrm{~d}$ & & & Coombs (1977) \\
\hline Viscera & 48 & & & & & & & & \\
\hline Gills & 24 & & & & & & & & \\
\hline Kidney & 203 & & & & & & & & \\
\hline Muscle & 7 & & & & & & & & \\
\hline Mantle & 47 & 200 & $47-59$ & $22-24$ & 15.5 & Semi-static & Jun & No & Present results \\
\hline Digestive & 180 & & & & & $3-4 \mathrm{~d}$ & & & \\
\hline Gills & 120 & & & & & & & & \\
\hline Foot & 39 & & & & & & & & \\
\hline Add. muscle & 32 & & & & & & & & \\
\hline $\begin{array}{l}\text { a Calculated fi } \\
\text { b Mature mus: }\end{array}$ & $\begin{array}{l}\text { rom regression line } \\
\text { sels }\end{array}$ & & & & & & & & \\
\hline
\end{tabular}


Table 5. Littorina littorea. Cadmium uptake rates in soft parts of periwinkles exposed to cadmium in seawater. Uptake rates have been calculated in the initial exposure period, where cadmium is taken up linearly with time. For semi-static exposure systems the intervals between water changes are given

\begin{tabular}{|c|c|c|c|c|c|c|c|c|}
\hline $\begin{array}{c}\text { Cadmium uptake } \\
\text { rate } \\
\left(\frac{\operatorname{\mu g~Cdg^{-1}\mathrm {dry}\text {wtd}} \mathrm{d}^{-1}}{\mu \mathrm{g} \mathrm{Cdml^{-1 }}}\right)\end{array}$ & 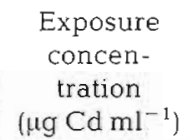 & $\begin{array}{l}\text { Soft part } \\
\text { dry wt } \\
\text { (mg) }\end{array}$ & $\begin{array}{l}\text { Salinity } \\
(\% 0)\end{array}$ & $\begin{array}{l}\text { Temper- } \\
\text { ature } \\
\left({ }^{\circ} \mathrm{C}\right)\end{array}$ & $\begin{array}{l}\text { Exposure } \\
\text { system }\end{array}$ & $\begin{array}{l}\text { Time } \\
\text { of year }\end{array}$ & Fed & Source \\
\hline 8 & 400 & $110 \pm 20$ & 33 & 15.4 & $\begin{array}{l}\text { Flow, tidal } \\
\text { tanks }\end{array}$ & Winter & No & $\begin{array}{l}\text { Langston \& } \\
\text { Zhou (1987) }\end{array}$ \\
\hline $\begin{array}{l}32 \\
24\end{array}$ & $\begin{array}{l}200^{\circ} \\
400^{\circ}\end{array}$ & - & 35 & 15.5 & $\begin{array}{l}\text { Semi-static } \\
1 \mathrm{~d}\end{array}$ & Winter & No & $\begin{array}{l}\text { Amiard et al. } \\
\text { (1987) }\end{array}$ \\
\hline 55 & 200 & $41-128$ & $21-23$ & 15.5 & $\begin{array}{l}\text { Semi-static } \\
3-4 \text { d }\end{array}$ & Aug & No & Present results \\
\hline
\end{tabular}

rates can probably be explained by the different exposure procedures. Salinity differences may explain why uptake rates in the present study exceed those of Amiard et al. (1987). Studies on uptake kinetics for cadmium in Arenicola marina and Asterias rubens have not previously been reported. Cadmium uptake kinetics in sea stars are apparently different from those of the 3 other species investigated here. Where the soft tissues of mussels, periwinkles and lugworms concentrate cadmium to several hundreds of $\mu \mathrm{g} \mathrm{Cd} \mathrm{g}{ }^{-1}$ dry wt, sea stars reach steady state levels of no more than 10 to $25 \mu \mathrm{g} \mathrm{Cd} \mathrm{g}{ }^{-1}$ dry wt. Shore crabs Carcinus maenas exposed to $200 \mu \mathrm{g} \mathrm{Cd} \mathrm{^{-1 }}$ under similar conditions reach cadmium concentrations of 50,10,30 and $12 \mu \mathrm{g} \mathrm{Cd} \mathrm{g}^{-1}$ dry wt in gills, carapace, hypodermis, and hepatopancreas after 4 wk (Bjerregaard 1988), and therefore the cadmium uptake rates for $A$. rubens cannot be considered to be exceptionally low. Finding that starfish Leptasterias polaris fed mercury-contaminated mussels do not accumulate mercury to very high levels, Pelletier \& Larocque (1987) suggested that sea stars possess an efficient detoxification/elimination mechanism for mercury. Such a mechanism might also operate in $A$. rubens with cadmium.

Although the concentration factor for cadmium in sea stars decreases at the highest cadmium concentrations tested, it is noteworthy that uptake in the sea stars is proportional to the ambient cadmium concentration from 25 to $2500 \mathrm{ng} \mathrm{Cd} \mathrm{l^{-1 }}$

Accumulation of cadmium in the blood of Arenicola marina exposed to $200 \mu \mathrm{g} \mathrm{Cd} \mathrm{l}^{-1}$ differs from the conditions in Carcinus maenas, which regulates haemolymph cadmium concentration below that of the surrounding medium if the cadmium concentration is lower than $4 \mathrm{mg} \mathrm{Cd} \mathrm{l}^{-1}$ (Wright 1977. Wright \& Brewer 1979, Bjerregaard \& Vislie 1985, Bjerregaard 1988).

\section{Effect of selenium on cadmium uptake}

Whereas selenium has no or only marginal effects on cadmium uptake in Mytilus edulis, Arenicola marina, and Littorina littorea the augmenting effect of selenium on cadmium uptake reported for Carcinus maenas (Bjerregaard 1982, 1985, 1988) was also seen in Asterias rubens. When exposed to cadmium alone, shore crabs (Bjerregaard 1988) and sea stars take up cadmium in their soft tissues 5 to 20 times more slowly than do mussels, periwinkles and lugworms, and it is interesting to note that, in the few species investigated, selenium only augments cadmium uptake in the species with the lowest cadmium uptake rate.

The mechanisms by which selenium augments cadmium uptake are not fully understood. Concurrent administration of selenite to cadmium-treated rats greatly increases the binding of cadmium in the blood plasma (Gasiewics \& Smith 1976, 1978, Nishiyama et al. 1987). Gasiewics \& Smith $(1976,1978)$ suggest that the effect of selenite on cadmium binding depends on the metabolic conversion of Se(IV) to Se(-II), which may form a protein-stabilized CdSe-complex with a molar ratio $\mathrm{Cd}$ :Se close to 1. A similar mechanism might be operating in the tissues of sea stars, but the $\mathrm{Cd}$ :Se ratio in the tissues shows some deviation from unity. However, in the pyloric caeca where surface adsorption can probably be excluded, the Cd:Se molar ratio approaches unity during 4 wk exposure.

Results indicate that selenite concentrations of 200 and $500 \mu \mathrm{g} \mathrm{Se}-\mathrm{SeO}_{3}^{--} 1^{-1}$ are lethal to small and medium sized sea stars, respectively, over 2 to $3 \mathrm{wk}$ exposure. For small sea stars it takes selenite concentrations of $\mathrm{ca} 15 \%$ of this concentration to augment cadmium uptake in whole organisms. It is possible that these selenite concentrations adversely affect the total 
metabolism of the sea star in a way that will inhibit normal elimination of cadmium from the organism. In medium sized sea stars and shore crabs Carcinus maenas cadmium uptake is affected by selenite concentrations 50 and 200 (Bjerregaard 1988) times, respectively, below the lethal concentrations, so a nonspecific mechanism hardly explains all of the interactions between cadmium and selenium in marine invertebrates.

Exposure to $50 \mu \mathrm{g} \mathrm{Se-SeO} \mathrm{S}^{--} \mathrm{l}^{-1}$ does not affect uptake of mercury from $30 \mu \mathrm{g} \mathrm{Hg} \mathrm{l}^{-1}$ in Mytilus edulis (Pelletier 1986), while $1000 \mu \mathrm{g} \mathrm{Se}-\mathrm{SeO}_{3}^{--} 1^{-1}$ augments mercury uptake from $100 \mu \mathrm{g} \mathrm{Hg}^{-1}$ in the clam Anadara granosa (Chandy \& Patel 1985). A similar effect of the selenite concentration may be present in the interaction between selenium and cadmium in bivalves, since 703 but not $141 \mu \mathrm{g} \mathrm{l^{-1 }}$ augments cadmium uptake in some tissues of $M$. edulis.

\section{Ecological impacts}

Whereas the behaviour of selenium in open ocean water has been well established during recent years (Measures \& Burton 1980, Measures et al. 1980, Cutter \& Bruland 1984), the behaviour in coastal waters seems more complex (Apte et al. 1986). In coastal waters and surface ocean waters selenite constitutes only a minor fraction of the total selenium concentration and values from $<2$ to $16 \mathrm{ng} \mathrm{Se}-\mathrm{SeO}_{3}^{--} 1^{-1}$ have been reported (Measures \& Burton 1980, Apte et al. 1986). In coastal areas with anthropogenic input of selenium, $\mu \mathrm{g} \mathrm{l}^{-1}$ quantities of selenium may be found locally (Ahsanullah \& Brand 1985, Phillips 1987). As selenite concentrations of ca $10 \mu \mathrm{g} \mathrm{Se-SeO} \mathrm{S}_{3}^{--}$augment cadmium uptake in sea stars in short-term experiments, cadmium concentrations in organisms living their whole lives in selenite polluted areas may be affected.

Acknowledgements. I thank Mrs V. Eriksen and Mr R. Stoving for technical assistance and Professor M. H. Depledge for critically reading the manuscript. The project was supported by a grant from the Danish Natural Science Research Council.

\section{LITERATURE CITED}

Ahsanullah, M., Brand, G. W. (1985). The effect of selenite and seliniferous fly-ash leachate on growth and viability of the marine amphipod Allorchestes compressa. Mar. Biol. 89: 245-248

Amiard, J. C., Amiard-Triquet, C., Berthet, B., Metayer, C. (1987). Comparative study of the patterns of bioaccumulation of essential $(\mathrm{Cu}, \mathrm{Zn})$ and non-essential $(\mathrm{Cd}, \mathrm{Pb})$ trace metals in various estuarine and coastal organisms. J. exp. mar. Biol. Ecol. 106: 73-89

Amiard-Triquet, C., Berthet, B., Metayer, C., Amiard, J. C.
(1986). Contribution to the ecotoxicological study of cadmium, copper and zinc in the mussel Mytilus edulis. II. Experimental study. Mar. Biol. 92: 7-13

Apte, S. C., Howard, A. G., Morris, R. J., McCartney, M. J. (1986). Arsenic, antimony and selenium speciation during a spring phytoplankton bloom in a closed experimental ecosystem. Mar Chem. 20: 119-130

Bjerregaard, P. (1982). Accumulation of cadmium and selenium and their mutual interaction in the shore crab Carcinus maenas (L.). Aquat. Toxicol. 2: 113-125

Bjerregaard, P. (1985). Effect of selenium on cadmium uptake in the shore crab Carcinus maenas (L.). Aquat. Toxicol. 7: $177-189$

Bjerregaard, P. (1988). Interaction between selenium and cadmium in the haemolymph of the shore crab Carcinus maenas (L.). Aquat. Toxicol. (in press)

Bjerregaard, P., Vislie, T. (1985). Effects of cadmium on hemolymph composition in the shore crab Carcinus maenas. Mar. Ecol. Prog. Ser 27: 135-142

Borchardt, $T$ (1983). Influence of food quantity on the kinetics of cadmium uptake and loss via food and seawater in Mytilus edulis. Mar. Biol. 76: 67-76

Chandy, J. P., Patel, B. (1985). Do selenium and glutathione (GSH) detoxify mercury in marine invertebrates? Effects on lysosomal response in the tropical blood clam Anadara granosa. Dis. aquat. Org. 1. 39-47

Cutter, G. A., Bruland, K. W. (1984). The marine biogeochemistry of selenium: a re-evaluation. Limnol. Oceanogr. 29: $1179-1192$

Fischer, H. (1986). Influence of temperature, salinity, and oxygen on the cadmium balance of mussels Mytilus edulis. Mar. Ecol. Prog. Ser. 32: 265-278

Fowler, S. W., Benayoun, G. (1974). Experimental studies on cadmium flux through marine biota. In: Comparative studies of food and environmental contamination. International Atomic Energy Agency, Vienna, p. 159-178

Gasiewics, T. A., Smith, J. C. (1976). Interactions of cadmium and selenium in rat plasma in vivo and in vitro. Biochim. Biophys. Acta 428, 113-122

Gasiewics, T A., Smith, J. C. (1978). Properties of the cadmium and selenium complex formed in rat plasma in vivo and in vitro. Chem. Biol. Interact. 23: 171-183

George, S. G., Carpene, E., Coombs, T L. (1977). The effect of salinity on the uptake of cadmium by the common mussel, Mytilus edulis (L.). In: McLusky, D. S., Berry, A. J. (eds.) Physiology and behaviour of marine organisms. Proceedings 12th European Symposium Peramon Press, Oxford, p. 189-193

George, S. G., Coombs, T L. (1977). The effects of chelating agents on the uptake and accumulation of cadmium by Mytilus edulis. Mar. Biol. 39: 261-268

Jackim, E., Morrison, G., Steele, R. (1977). Effects of environmental factors on radiocadmium uptake by four species of marine bivalves. Mar. Biol. 40: 303-308

Janssen, H. H., Scholz, N. (1979). Uptake and cellular distribution of cadmium in Mytilus edulis. Mar. Biol. 55: 133-141

Kar, A. B., Das, R. P., Mukerji, F. N. I. (1960). Prevention of cadmium induced changes in the gonads of rat by zinc biological system. Proc. natl Inst. Sci. India. Pt B. 26 (Suppl.): 40-50

Köhler, K., Riisgaard, H. U. (1982). Formation of metallothioneins in relation to accumulation of cadmium in the common mussels Mytilus edulis. Mar. Biol. 66: 53-58

Langston, W. J., Zhou, M. (1987). Cadmium accumulation, distribution and metabolism in the gastropod Littorina littorea: the role of metal-binding proteins $\mathrm{J}$ mar. biol. Ass. U.K. 67: 585-601 
Mackay, N. J., Kazacos, M. N., Williams, R. J., Leedow, M. I. (1975). Selenium and heavy metals in black marlin. Mar Pollut. Bull, 6: 57-61

Magnusson, B., Rasmussen, L. (1982). Trace metal levels in coastal sea water. Investigation of Danish waters. Mar Pollut. Bull. 13: 81-84

Magos, L., Webb, M. (1980). The interactions of selenium with cadmium and mercury. CRC Crit. Rev. Toxicol. 8: 1-42

Measures, C. I., Burton, J. D. (1980). The vertical distribution and oxidation states of dissolved selenium in the northeast Atlantik Ocean and their relationship to biological processes. Earth Plant. Sci. Lett. 46: 385-396

Measures, C. I., McDuff, R. E., Edmond, J. M. (1980). Selenium redox chemistry at Geosecs I re-occupation. Earth Planet. Sci. Lett. 49: 102-108

Nishiyama, S., Nakamura, K., Konishi, Y. (1987). Effect of selenium on blood pressure, urinary sodium excretion and plasma aldosterone in cadmium-treated male rats. Arch. Toxicol. 59: 365-370

Norheim, G. (1987). Levels and interactions of heavy metals in sea birds from Svalbard and the Antarctic. Environ. Pollut. 47: 83-94

Pelletier, E. (1985). Mercury-selenium interactions in aquatic organisms: a review. Mar. environ.Res. 18: 111-132

Pelletier, E. (1986). Modification de la bioaccumulation du sélénium chez Mytilus edulis en présence du mercure organique et inorganique. Can. J. Fish. Aquat. Sci. 43 203-210

Pelletier, E., Larocque, R. (1987). Bioaccumulation of mercury in starfish from contaminated mussels. Mar. Pollut. Bull. 18: $482-485$

Phillips, D. J. H. (1987). Toxic contaminants in the San Francisco Bay-Delta and their possible biological effects. Technical Report of the Aquatic Habitat Institute, 1301 South 46th St, Richmond, California 94804, USA

Poulsen, E., Riisgaard, H. U., Mohlenberg, F. (1982). Accumulation of cadmium and bioenergetics in the mussel Mytilus edulis. Mar. Biol. 68: 25-29

Puymbroeck, S. L. C. van, Stips, W. J. J., Vanderborght, O. L. $\mathrm{J} .(1982)$. The antagonism between selenium and cadmium in a freshwater mollusc. Arch. environ. Contam. Toxicol. $11,103-106$

Riisgaard, H. U., Bjørnestad, E., Møhlenberg, F. (1987). Accumulation of cadmium in the mussel Mytilus edulis: kinetics and importance of uptake via food. Mar. Biol. 96: 349-353

Shimoishi, Y. (1976). The gas-chromatographic determination of selenium (VI) and total selenium in milk, milk products and albumin with 1,2-diamino-4-nitrobenzene. Analyst 101: 298-305

Sokal, R. R., Rohlf, F. J. (1969). Biometry. The principles and practice of statistics in biological research. Freeman \& Co., San Francisco

Wright, D. A. (1977). The effect of salinity on cadmium uptake by the tissues of the shore crab Carcinus maenas. J. exp. Biol. 67: 137-146

Wright, D. A., Brewer, C. C. (1979). Cadmium tumover in the shore crab Carcinus maenas. Mar. Biol. 50: 151-156

This article was submitted to the editor; it was accepted for printing on June 20, 1988 